\title{
Diversity of water-borne conidial fungi in some freshwater bodies of Kumaun Himalaya in district Nainital (Uttarakhand), India
}

\author{
Ruchi Jalal* \\ Department of Botany, I.P.G.G.P.G. College of Commerce, Haldwani-263139 (Uttarakhand), \\ India \\ Saraswati Bisht \\ Department of Botany, I.P.G.G.P.G. College of Commerce, Haldwani-263139 (Uttarakhand), \\ India \\ Saima Altaf \\ Department of Botany, I.P.G.G.P.G. College of Commerce, Haldwani-263139 (Uttarakhand), \\ India \\ Anjali Tiwari \\ Department of Botany, I.P.G.G.P.G. College of Commerce, Haldwani-263139 (Uttarakhand), \\ India \\ *Corresponding author. E. mail: ruchijalal13@gmail.com
}

\section{How to Cite}

Jalal, R. et al. (2020). Diversity of water-borne conidial fungi in some freshwater bodies of Kumaun Himalaya in district Nainital (Uttarakhand), India. Journal of Applied and Natural Science, 12(4):484 - 490. https://doi.org/10.31018/jans.v12i4.2370

\begin{abstract}
The aquatic ecosystem harbours a variety of micro-organisms, among which water-borne conidial fungi occupy an important place. Their occurrence in freshwater habitat has great significance in the decomposition of submerged plant materials, nutrient release and productivity. Their occurrence and frequency to extreme temperatures and $\mathrm{pH}$ may have a profound effect on fungal community composition and metabolic activities. The present paper deals with the diversity of conidial aquatic fungi from different unexplored freshwater bodies flowing through different elevations (1000-1500 m) in district Nainital, Kumaun Himalaya. Comparative study of species composition in different seasons, sporulation temperatures and $\mathrm{pH}$ conditions was also carried out. In all, 18 species of conidial fungi belonging to 14 genera were recorded, out of which maximum species (11 species) were recorded in both rainy (July to September) and winter seasons (November to December). Anguillospora crassa, Beltrania rhombica, Campylospora chaetocladia, Cylindrocarpon aquaticum, Helicomyces roseus and Tetracladium setigerum were isolated only during rainy season; Alatospora acuminata, Clavariopsis aquatica, Clavatospora tentacula, Lemonniera pseudofloscula, $L$. terrestris and Tetrachaetum elegans were isolated only during winter season while Lunulospora curvula, L. cymbiformis, Setosynnema isthmosporum, Tetracladium marchalianum and Triscelophorus acuminatus were isolated in both rainy and winter seasons. The preferred $\mathrm{pH}$ and the sporulation temperature ranged from $6-7$ and $15-20{ }^{\circ} \mathrm{C}$ respectively. The results of the present study are clearly indicating fungal species composition variations along $\mathrm{pH}$, temperature, seasonal and altitudinal gradients and the sites selected for this exploratory investigation are being undertaken for the first time.
\end{abstract}

Keywords: Aquatic ecosystems, Bio-monitors, Conidial fungi, Decomposition, Species composition

\section{INTRODUCTION}

Fungi inhabiting the submerged decomposed leaf litters in stream and river waters are referred to as aquatic hyphomycetes, freshwater hyphomycetes, amphibious hyphomycetes, Ingoldian fungi, waterborne conidial fungi etc. The pioneer studies of Professor C.T. Ingold (1942) were the most significant contributions to advert to these fungi. Water-borne conidial fungi are deutromycetous fungi characterized by producing distinctive shapes of conidia colonizing deciduous leaves, decaying in freshwater bodies (Ingold, 1975). The shapes of conidia and their attachment with conidiophores help in identification and characteri- zation of these conidial fungi (Barlocher and Marvanova, 2010). The altitudinal and seasonal differences in diversity of these fungi may be due to physicochemical properties of water, nutrient and substrate availability (Pant et al., 2019). Environmental variables such as temperature and $\mathrm{pH}$ are also the dominant factors that affect the growth of these fungi (Duarte et al., 2013; Bai et al., 2018). Their occurrence and frequency to extreme temperatures and $\mathrm{pH}$ may have a profound effect on fungal community composition and metabolic activities. For example, temperate species are found to survive at freezing temperatures and tropical species may survive at higher temperatures 
(Sridhar and Barlocher, 1993; Krauss et al., 2011).

Freshwater ecosystems comprise complex food webs in which each species plays an essential role as producer and consumer. Among those, water-borne conidial fungi are known to fulfil an important and unique function of degrading allochthonous dead plant litter allowing the transfer of resulting energy and nutrients to higher trophic levels (Gulis, 2019). Therefore, the hidden aspects of these fungi are needed to be studied with great pace from unexplored areas.

Kumaun Himalaya, a temperate climatic zone with many water bodies at different elevations having a rich source of substrate pool provides suitable habitat for the growth of diversified forms of water-borne conidial fungi. A substantial contribution on these fungi from this region has been made earlier (Sati et al., 2002; Sati et al., 2009; Pant and Sati, 2018, Pant et al., 2019).

The present study was undertaken to know the species diversity of water-borne conidial fungi from some unexplored areas of Kumaun Himalaya along an altitudinal gradient $(1000-1500 \mathrm{~m})$ and to assess species composition of these fungi along different seasons, $\mathrm{pH}$ preferences and temperature requirements.

\section{MATERIALS AND METHODS}

Study area: The present study was carried out in different unexplored streams flowing along varied localities viz., Ramgaarh, Kulgarh and Devdwar. Ramgaarh region $(\approx 1000 \mathrm{~m})$ is situated near Haldwani-Almora highway. A small hydropower project by Uttarakhand Renewable Energy Developmental Agency (UREDA) is established on the stream to provide electricity to the nearby villages. Kulgarh region $(\approx 1100 \mathrm{~m})$ is situated in Nainital district (Uttarakhand) also known for Dhokaney waterfall, and Devdwar region $(\approx 1500 \mathrm{~m})$ is situated in Kosya Kutoli, Nainital.

Collection and processing: Submerged decomposed leaf litter was collected in pre-sterilized polythene bags seasonally from summer (April to June), rainy (July to September), winter (November to December), 2019 and brought to the laboratory. The collected samples were washed thoroughly under running tap water to remove soil particles and other extracellular debris. The leaf litter was then cut into small pieces and placed into pre-sterilized Petri dishes containing distilled water for incubation at room temperature. After 2-3 days of incubation, samples were regularly examined under low power of a compound microscope to detect the conidia of water-borne conidial fungi. Water $\mathrm{pH}$ was also measured with the help of portable $\mathrm{pH}$ meter on the spot during collection and the sporulating temperatures of different fungal species in different seasons were measured by using room thermometer.

Identification of fungal species: Conidia were picked aseptically and placed on $2 \%$ malt extract agar (MEA) supplemented with streptomycin to obtain Axenic cul- tures. Semi-permanent slides of these conidia were prepared using lactophenol cotton blue stain and deposited in Govt. Girls College Mycological Slide (GGCMS) collection of Department of Botany, Haldwani (Nainital). Photomicrographs and Camera Lucida drawings of conidia were prepared and compared with pertinent literature for identification (Ingold, 1975; Santos and Betancourt, 1997).

\section{RESULTS AND DISCUSSION}

During the present study, 18 species of water-borne conidial fungi belonging to 14 genera were isolated and identified from submerged decomposed leaf-litters collected from different streams of Ramgaarh, Kulgarh and Devdwar at an altitudinal range of 1000-1500 m (Fig. 1a, 1b; Plate 1; Table 1). Comparison of species composition along altitudinal gradients in relation to temperature and $\mathrm{pH}$ requirements is represented graphically (Fig. 2, 3).

\section{Taxonomic description}

Alatospora acuminata Ingold (Plate 1. A; Fig. 1a. A) : Conidia collected from Ramgaarh, Kulgarh and Devdwar in summer (April to June) and winter (November to December) seasons at water $\mathrm{pH} 7$ and 8 , sporulation temperature ranging from $17-30{ }^{\circ} \mathrm{C}$, were hyaline, tetra radiate, with curved main axis 21 $40 \mu \mathrm{m}$ long, and two curved appendages 25-50 $\mu \mathrm{m}$ long having 3-4 septations.

Anguillospora crassa Ingold (Plate 1. B; Fig. 1a. B): Conidia collected from Ramgaarh, Kulgarh and Devdwar in summer (April to June) and rainy (July to September) seasons at water $\mathrm{pH} 6$ and 8, sporulation temperature ranging from $30-32{ }^{\circ} \mathrm{C}$, were hyaline, vermiform, 90-200 $\mu \mathrm{m}$ long, 10-20 $\mu \mathrm{m}$ wide, 5-10 septate, tapering towards ends.

Anguillospora longissima (Sacc. And Syed) Ingold (Plate 1. C; Fig. 1a. C) : Conidia collected from Ramgaarh in summer (April to June) season at water $\mathrm{pH} 8$, sporulation temperature ranging from $30-36{ }^{\circ} \mathrm{C}$, were hyaline, unbranched, filiform, curved with main axis 150-350 $\mu \mathrm{m}$ long, 4-6 $\mu \mathrm{m}$ wide at middle having 5-12 septations, tapering at both the ends.

Beltrania rhombica Penzig (Plate 1. D; Fig. 1a. D): Conidia collected from Devdwar in rainy (July to September) season at water $\mathrm{pH} \mathrm{6,} \mathrm{sporulation} \mathrm{temperature}$ ranging from $30-32{ }^{\circ} \mathrm{C}$ were light-brown to pale-olive, consisting of a bi-conic, symmetrical, main axis, 16-30 $\mu \mathrm{m}$ long, 6-9 $\mu \mathrm{m}$ wide, with a distinct, hyaline, transverse band and an apical, hyaline 10-15 $\mu \mathrm{m}$ long appendage with a basal septum.

Campylospora chaetocladia Ranzoni (Plate 1. E; Fig. 1a. E): Conidia collected from Kulgarh in rainy (July to September) season at water $\mathrm{pH} \mathrm{6,} \mathrm{sporulation}$ temperature ranging from $20-30{ }^{\circ} \mathrm{C}$ were tetra radiate, main axis alantoid, composed of a smaller part 10-15 $\mu \mathrm{m}$ in length and 8-11 $\mu \mathrm{m}$ in width, while arms are 27$38 \mu \mathrm{m}$ long. Apical cells of axis conoid to bulbous, each end in one of the slender appendages. 
Clavariopsis aquatica (De Wildeman) Ingold (Plate 1. F; Fig. 1a. F): Conidia collected from Ramgaarh and Devdwar in summer (April to June) and winter (November to December) seasons at water $\mathrm{pH} 7$ and 8 , sporulation temperature ranging from $17-30^{\circ} \mathrm{C}$ were hyaline, 2-3 celled obconical main axis, 25- $60 \mu \mathrm{m}$ long, 10-16 $\mu \mathrm{m}$ wide, lateral arms arising from the broad end of the $1^{\text {st }}$ arm are 20- $100 \mu \mathrm{m}$ long. Usually, appendages or arms are longer than the axis.

Clavatospora tentacula Nilsson (Plate 1. G; Fig. 1a. G): Conidia collected from Kulgarh in winter (November to December) season at water $\mathrm{pH} 7$, sporulation temperature ranging from $15-17{ }^{\circ} \mathrm{C}$ were tetraradiate, main axis $30-75 \mu \mathrm{m}$ long and 1.5-2.5 $\mu \mathrm{m}$ wide at the base, 4-7 $\mu \mathrm{m}$ wide at apex, with 3-equidistant, divergent 30-55 $\mu \mathrm{m}$ long and 1-2 $\mu \mathrm{m}$ wide appendages arising from the apex and constricted the base.

Cylindrocarpon aquaticum Nilsson (Plate1. H; Fig. 1a. H): Conidia collected from Ramgaarh, Kulgarh and Devdwar in summer (April to June) and rainy (July to September) seasons at water $\mathrm{pH} 6$ and 8 sporulation temperature ranging from $27-30{ }^{\circ} \mathrm{C}$ were brown, cylindrical, small, septate and measured up-to 15-18 $\mu \mathrm{m}$ in length and 3-4 $\mu \mathrm{m}$ in width.

Helicomyces roseus Link (Plate 1. I; Fig. 1a. I): Conidia collected from Ramgaarh and Devdwar in rainy (July to September) season at water $\mathrm{pH} 6$ sporulation temperature ranging from $30-32{ }^{\circ} \mathrm{C}$ were helical, coiled up to 2.5-3 times with rounded ends, 20-30 $\mu \mathrm{m}$ in diameter with $10-15$ septa, tapering to an enlarge, obliquely flattened basal cell.

Lemonniera pseudofloscula Dyko (Plate1. J; Fig. 1b. A): Conidia collected from Kulgarh and Devdwar in winter (November to December) season at water $\mathrm{pH} 7$ sporulation temperature ranging from $17-20{ }^{\circ} \mathrm{C}$ were hyaline, tetra-radiate, main axil cell spherical 3-6 $\mu \mathrm{m}$ in diameter, 1-6 septations, consisting of 3-4 appendages, 13-72 $\mu \mathrm{m}$ long and 3-4 $\mu \mathrm{m}$ wide.

Lemonniera terrestris Tubaki (Plate1. K; Fig. 1 b. B): Conidia collected from Kulgarh in winter (November to December) season at water $\mathrm{pH} 7$, sporulation temperature ranging from $17-20^{\circ} \mathrm{C}$ were hyaline, tetra-radiate main axil cell spherical 4-7 $\mu \mathrm{m}$ in diameter, appendages 9-13 $\mu \mathrm{m}$ long and 3-6 $\mu \mathrm{m}$ wide. Lunulospora curvula Ingold (Plate 1. L; Fig. $1 \mathrm{~b}$. C): Conidia collected from Ramgaarh, Kulgarh and Devdwar in rainy (July to September) and winter (November to December) seasons at water $\mathrm{pH} 6$ and 7 , sporulation temperature ranging from $17-28{ }^{\circ} \mathrm{C}$ were hyaline, lunate, unbranched, elongated, aseptate, dematiaceous conidia 40-50 $\mu \mathrm{m}$ long and 4-6 $\mu \mathrm{m}$ wide.

Lunulospora cymbiformis Miura (Plate 1. M; Fig. 1b. D): Conidia collected from and Devdwar in rainy (July to September) and winter (November to December) seasons at water $\mathrm{pH} 6$ and 7 , sporulation temper-

Table 1. Species composition of water-borne conidial fungi in different streams.

\begin{tabular}{|c|c|c|c|c|c|c|}
\hline S. No. & Species & $\begin{array}{l}\text { Conidial } \\
\text { shape }\end{array}$ & Place & Season & $\begin{array}{l}\text { Sporulation } \\
\text { Temperature } \\
\left(\text { in }^{\circ} \mathrm{C}\right)\end{array}$ & $\mathrm{pH}$ \\
\hline 1. & Alatospora acuminata & Tetraradiate & $\mathrm{R}, \mathrm{Ku}, \mathrm{D}$ & S, W & $17-30$ & 7,8 \\
\hline 2. & Anguillospora crassa & Vermiform & $\mathrm{R}, \mathrm{Ku}, \mathrm{D}$ & $S, R$ & $30-32$ & 6,8 \\
\hline 3. & Anguillospora longissima & $\begin{array}{l}\text { Sigmoid or } \\
\text { Filiform }\end{array}$ & $\mathrm{R}$ & $S$ & $30-36$ & 8 \\
\hline 4. & Beltrania rhombica & Rhomboid & $\mathrm{D}$ & $\mathrm{R}$ & $30-32$ & 6 \\
\hline 5. & Campylospora chaetocladia & Tetraradiate & $\mathrm{Ku}$ & $\mathrm{R}$ & $20-30$ & 6 \\
\hline 6. & Clavariopsis aquatica & Obconical & $R, D$ & S, W & $17-30$ & 7,8 \\
\hline 7. & Clavatospora tentacula & Tetraradiate & $\mathrm{Ku}$ & W & $15-17$ & 7 \\
\hline 8. & Cylindrocarpon aquaticum & Cylindrical & $\mathrm{R}, \mathrm{Ku}, \mathrm{D}$ & $S, R$ & $27-30$ & 6,8 \\
\hline 9. & Helicomyces roseus & Helicoid & $R, D$ & $\mathrm{R}$ & $30-32$ & 6 \\
\hline 10. & Lemonniera pseudofloscula & Tetraradiate & $\mathrm{Ku}, \mathrm{D}$ & W & $17-20$ & 7 \\
\hline 11. & Lemonniera terrestris & Tetraradiate & $\mathrm{Ku}$ & W & $17-20$ & 7 \\
\hline 12. & Lunulospora curvula & Sigmoid & $\mathrm{R}, \mathrm{Ku}, \mathrm{D}$ & $\mathrm{R}, \mathrm{W}$ & $17-28$ & 6,7 \\
\hline 13. & Lunulospora cymbiformis & Sigmoid & $\mathrm{D}$ & $\mathrm{R}, \mathrm{W}$ & $17-28$ & 6,7 \\
\hline 14. & Setosynnema isthmosporum & Sigmoid & $\mathrm{R}, \mathrm{Ku}, \mathrm{D}$ & $\mathrm{R}, \mathrm{W}$ & $17-25$ & 6,7 \\
\hline 15. & Tetrachaetum elegans & Tetraradiate & $\mathrm{D}$ & W & $15-20$ & 7 \\
\hline 16. & Tetracladium marchalianum & Tetraradiate & $\mathrm{R}, \mathrm{Ku}, \mathrm{D}$ & $\mathrm{S}, \mathrm{R}, \mathrm{W}$ & $15-30$ & $6,7,8$ \\
\hline 17. & Tetracladium setigerum & Multiradiate & $\mathrm{Ku}$ & $\mathrm{R}$ & $17-20$ & 6 \\
\hline 18. & Triscelophorus acuminatus & Tetraradiate & $\mathrm{R}, \mathrm{Ku}, \mathrm{D}$ & $\mathrm{R}, \mathrm{W}$ & $20-32$ & 6,7 \\
\hline
\end{tabular}

Place- D- Devdwar ( $\approx 1500 \mathrm{~m})$, Ku-Kulgarh ( $\approx 1100 \mathrm{~m}), \mathrm{R}$ - Ramgaarh $(\approx 1000 \mathrm{~m})$

Seasons- S- Summer (April to June), R- Rainy (July to September), W- Winter (November to December) 


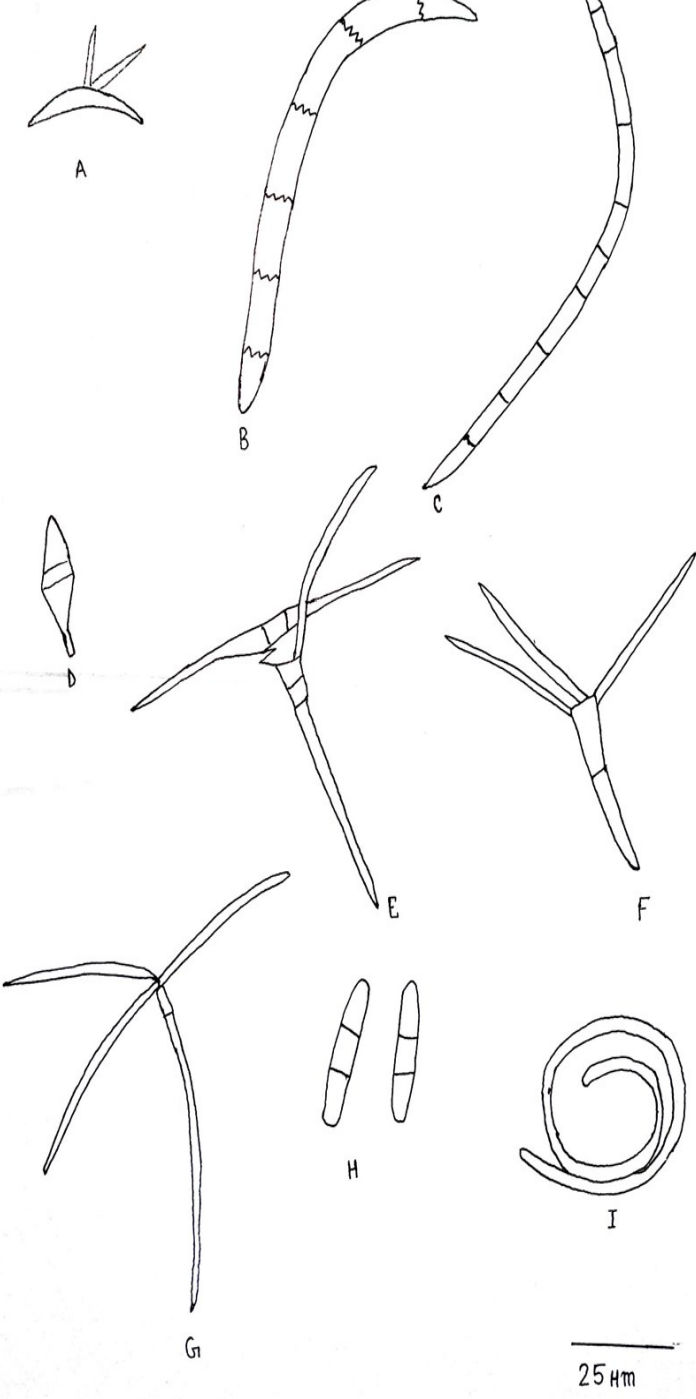

Fig. 1 a. Camera lucida drawings of water borne conidial fungi A: Alatospora acuminata, B: Anguillospora crassa, C: A. longissima, D: Beltrania rhombica, E: Campylospora chaetocladia, F: Clavariopsis aquatica, G: Clavatospora tentacula, $\mathrm{H}$ : Cylindrocarpon aquaticum, I: Helicomyces roseus. Scale bar- $25 \mu \mathrm{m}$

ature ranging from $17-28{ }^{\circ} \mathrm{C}$ were hyaline to light green, sickle-shaped, aseptate dematiaceous conidia bent at right angle, 40-50 $\mu \mathrm{m}$ long and 3-5 $\mu \mathrm{m}$ wide with a characteristic scar in the middle.

Setosynnema isthmosporum Shaw and Sutton (Plate 1. N; Fig. 1b. E): Conidia collected from Ramgaarh, Kulgarh and Devdwar in rainy (July to September) and winter (November to December) seasons at water $\mathrm{pH} 6$ and 7 , sporulation temperature ranging from $17-25{ }^{\circ} \mathrm{C}$ were sigmoid $150-200 \mu \mathrm{m}$ long, 3-4 $\mu \mathrm{m}$ wide, tapering towards the tips, 6-7 septate.

Tetrachaetum elegans Ingold (Plate 1. 0; Fig. 1 b. F): Conidia collected from Devdwar in winter (November to December) season at water $\mathrm{pH} 7$, sporulation temperature ranging from $15-20{ }^{\circ} \mathrm{C}$ were hyaline, tetra-radiate, main axis bent at the insertion of 2

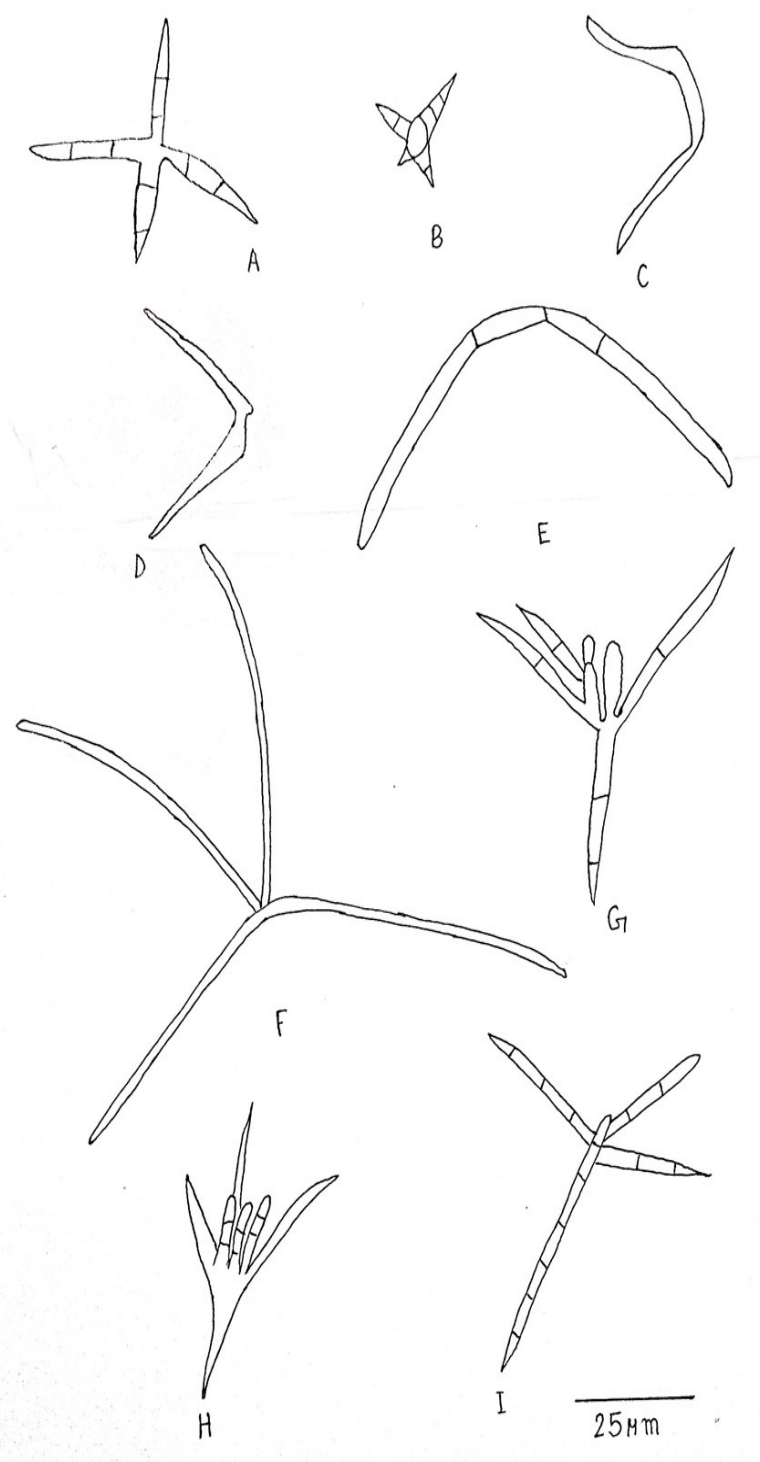

Fig. 1b. Camera lucida drawings of water borne conidial fungi. A: Lemonniera pseudofloscula, B: L. terrestris, C: Lunulospora curvula, D: L. cymbiformis, E: Setosynnema isthmosporum, F: Tetrachaetum elegans, G: Tetracladium marchalianum, $\mathrm{H}$ : T. setigerum, I: Triscelophorus acuminatus. Scale bar- $25 \mu \mathrm{m}$

appendages, main axis 130-200 $\mu \mathrm{m}$ long, arms $50-150$ $\mu \mathrm{m}$ long and uniform in width with 6-8 septations.

Tetracladium marchalianum de Wild (Plate 1. P; Fig. 1b. G): Conidia collected from Ramgaarh, Kulgarh and Devdwar in summer (April to June), rainy (July to September) and winter (November to December) seasons at water $\mathrm{pH}$ 6-8, sporulation temperature ranging from $15-30{ }^{\circ} \mathrm{C}$ were tetra-radiate, with two spherical knobs (one central and one eccentric), the main axis is $15-20 \mu \mathrm{m}$ long, while the central knob is 9$12 \mu \mathrm{m}$ long, septations not prominent.

Tetracladium setigerum Grove (Plate 1. Q; Fig. 1b. H): Conidia collected from Kulgarh in rainy (July to September) season at water $\mathrm{pH} 6$, sporulation temperature ranging from $17-20^{\circ} \mathrm{C}$ were hyaline, $12-15 \mu \mathrm{m}$ long and 3-4 $\mu \mathrm{m}$ wide with 3-6 septations, conidial axis 

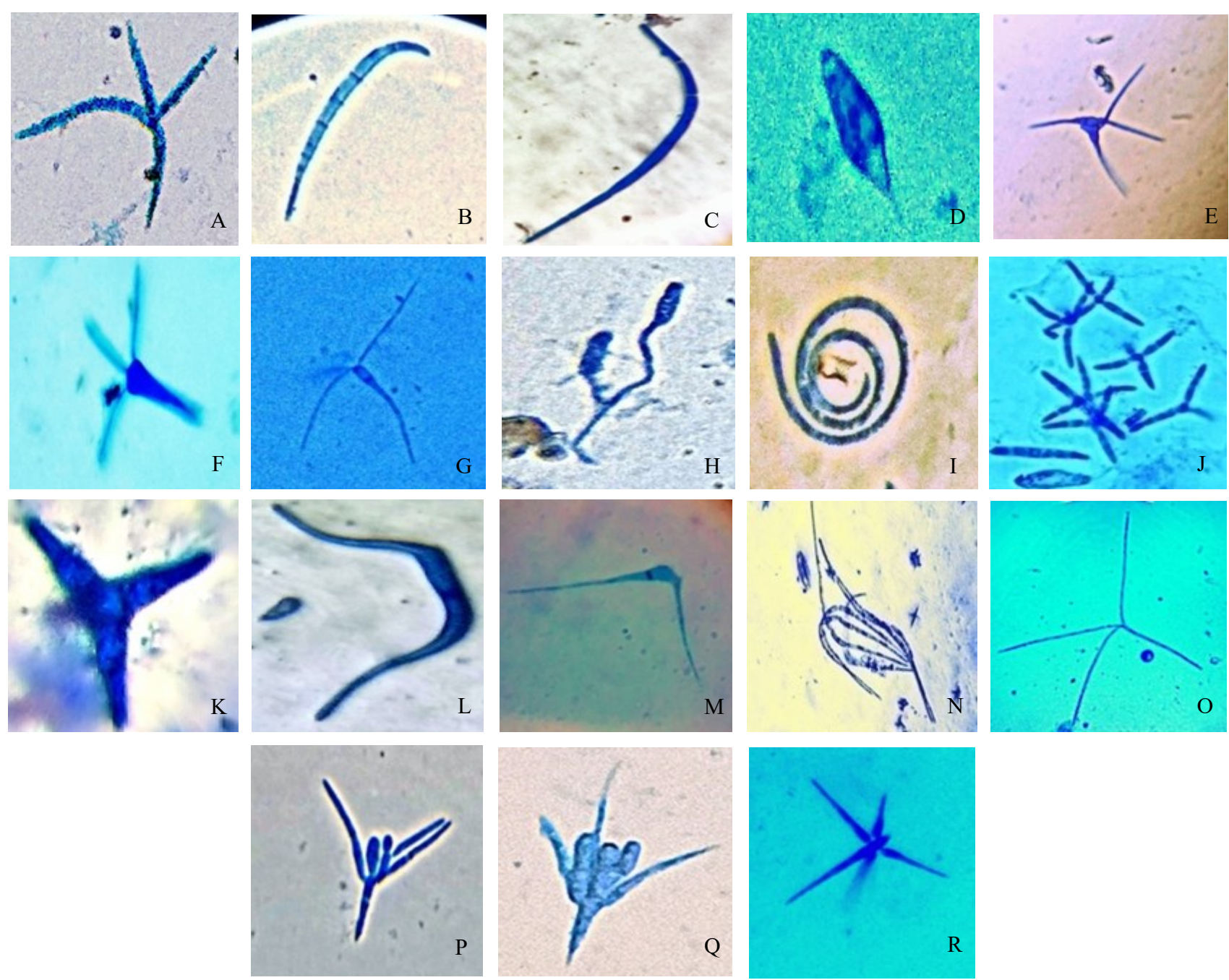

Plate 1: Photomicrographs- A: Alatospora acuminata, B: Anguillospora crassa, C: A. longissima, D: Beltrania rhombica, E: Campylospora chaetocladia, F: Clavariopsis aquatica, G: Clavatospora tentacula, H: Cylindrocarpon aquaticum, I: Helicomyces roseus, J: Lemonniera pseudofloscula, K: L. terrestris, L: Lunulospora curvula, M: L. cymbiformis, N: Setosynnema isthmosporum, O: Tetrachaetum elegans, P: Tetracladium marchalianum, Q: T. setigerum, R: Triscelophorus acuminatus.

distally digit form. The knobs are 5-12 $\mu \mathrm{m}$ long with 13 septations.

Triscelophorus acuminatus Nawawi (Plate 1. R; Fig. 1b. I): Conidia collected from Ramgaarh, Kulgarh and Devdwar in rainy (July to September) and winter (November to December) seasons at water $\mathrm{pH} 6$ and 7 , sporulation temperature ranging from $20-32{ }^{\circ} \mathrm{C}$ were hyaline, variable in size and shape, the main axis is $30-50 \mu \mathrm{m}$ long, gradually tapering at tip; the lateral arms are 27-36 $\mu \mathrm{m}$ in length.

Thus, in the present study, out of 14 genera, 10 genera were recorded with single species and the rest 4 genera namely, Anguillospora, Lemonniera, Lunulospora, and Tetracladium were found with 2 species each. A perusal of seasonal occurrence of different species in the habitat indicates that most of the waterborne conidial fungi showed a marked fluctuation in their occurrence (Sati and Arya, 2009). In the present study, maximum species (11 species) were recorded in both rainy (July to September) and winter seasons (November to December). A. crassa, B. rhombica, C. chaetocladia, C. aquaticum, $H$. Roseus and $T$. setigerum were isolated only during rainy season; $A$. acuminata, C. aquatica, C. tentacula, L. pseudofloscula, $L$. terrestris and $T$. elegans were isolated only during winter season while L. curvula, L. cymbiformis, $S$. isthmosporum, T. marchalianum and T. acuminatus were isolated in both rainy and winter seasons. Least species (6 species) viz., $A$. acuminata, $A$. crassa, $A$. longissima, $C$. aquatica, $C$. aquaticum and $T$. marchalianum were recorded during summer season (April to June). This may be due to high temperature $\left(>30^{\circ} \mathrm{C}\right.$ ) and high $\mathrm{pH}(8)$ in summers and moderate to low temperature $\left(15-30^{\circ} \mathrm{C}\right)$ and acidic to neutral $\mathrm{pH}(6$ $-7)$ in rainy and winter seasons. The $\mathrm{pH}$ of water bodies differed seasonally from $6-8$, being maximum during summer and minimum during the rainy season. The $\mathrm{pH}$ condition between 6-7 favoured maximum 


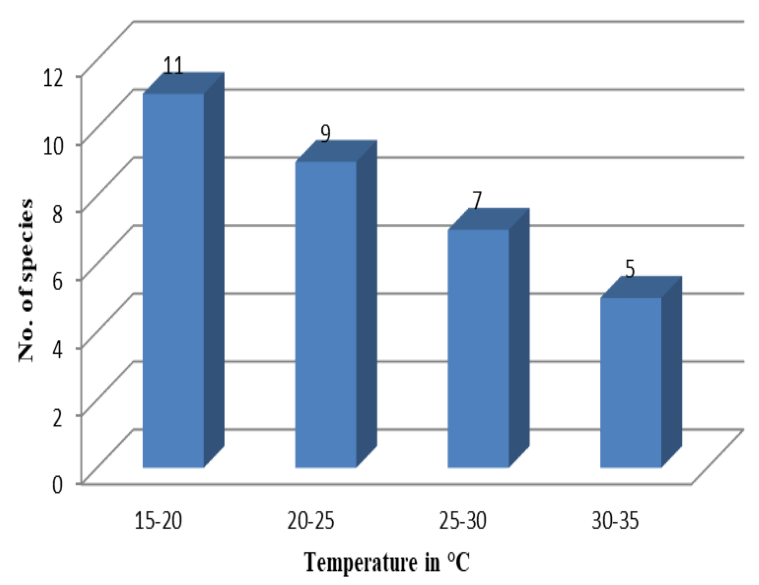

Fig. 2. Species occurrence in different sporulation temperature ranges.

growth of these fungi and the sporulation temperature between $15-20^{\circ} \mathrm{C}$ was found to be optimal (Fig. 2 and 3). Many investigators have also observed similar results that the water-borne conidial fungi show maximum growth in rainy and winter seasons due to low temperature and $\mathrm{pH}$ (6-7) (Barlocher, 1987; Belwal and Sati, 2001; Dang et al., 2009; Krauss et al. 2011). It was interesting to note that altitudinal variations considerably influenced the species composition of water-borne conidial fungi in all the selected sites. $A$. longissima was isolated only from Ramgaarh stream ( $\approx 1000 \mathrm{~m}) ;$ C. chaetocladia, C. tentacula, L. terrestris and $T$. setigerum were isolated only from Kulgarh stream ( $\approx 1100 \mathrm{~m}$ ); while $B$. rhombica, L. cymbiformis and $T$. elegans were isolated only from Devdwar stream $(\approx 1500 \mathrm{~m})$. This may be because of the temperature and altitudinal preferences of different species that they are linked to geographical distribution, and some species are common in temperate regions while some in tropical regions. Some temperate species are found to survive at freezing temperatures, and tropical species may survive at higher temperatures as reported by Sridhar and Barlocher, (1993) and Krauss et al. (2011).

Further, out of the 18 species isolated from different streams, T. marchalianum was found to occur throughout the year from all the sites. This may be regarded as temperature tolerant and common species of all the streams. The observed results are also supported by the studies of Duarte et al. (2013) and Bai et al. (2018) in that the environmental variables such as temperature, $\mathrm{pH}$, nutrient availability, altitudinal variations can affect fungal community composition.

\section{Conclusion}

On the basis of the present study, it is concluded that seasonal and altitudinal variations greatly influence the species composition of water-borne conidial fungi in different water bodies of Kumaun Himalaya in Uttarakhand. The rainy (July to September) and winter seasons (November to December) supported maxi-

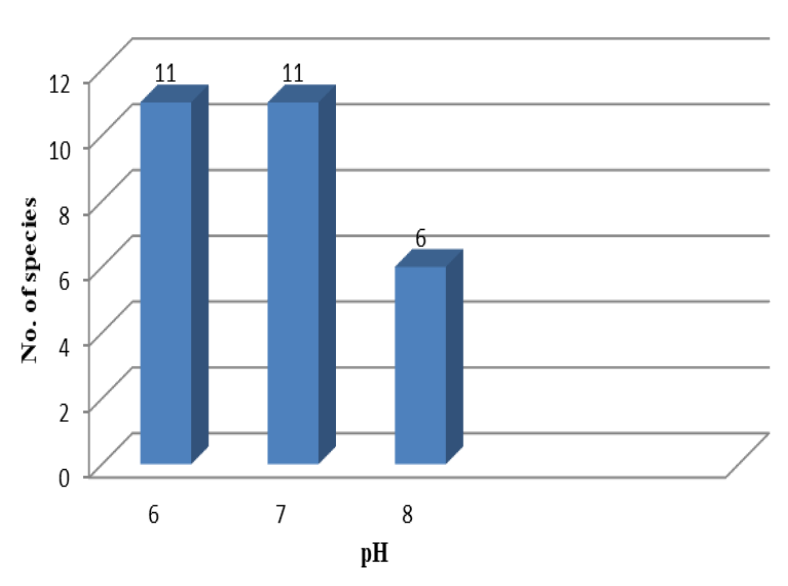

Fig. 3. Species occurrence in different $\mathrm{pH}$ conditions.

mum growth (11 species), while minimum growth (6 species) was recorded in summer season (April to June). 13 species were isolated from high altitude stream i.e. Devdwar $(1500 \mathrm{~m})$ and 10 species were isolated from Ramgaarh $(1000 \mathrm{~m})$ a low altitude stream. T. marchalianum was found to occur throughout the year from all the sites. Thus it may be regarded as temperature tolerant and common species of all the streams. These fungi were best sporulated at $15-20{ }^{\circ} \mathrm{C}$ and preferred $\mathrm{pH}$ (6-7) slightly acidic to neutral. This study gives a brief account of the diversity of Hyphomycetous fungi from some unexplored water bodies flowing through different altitudinal ranges of Kumaun Himalaya and also provided a database for altitudinal impact on species composition of water-borne conidial fungi.

\section{ACKNOWLEDGEMENTS}

Authors are thankful to Prof. Shashi Purohit, Principal, I.P.G.G.P.G. College of Commerce, Haldwani for providing necessary lab facilities. We are also grateful to Dr. S.D. Tewari, Head of the Department and Dr. Prachi Joshi, Assistant Professor, Dept. of Botany, I.P.G.G.P.G. College of Commerce, Haldwani for their valuable guidance and support.

\section{Conflict of interest}

The authors declare that they have no conflict of interest.

\section{REFERENCES}

1. Bai, Y., Wang, Q., Liao, K., Jian, Z., Zhao, C. and Qu, J. (2018). Fungal Community as a Bioindicator to Reflect Anthropogenic Activities in a River Ecosystem. Frontiers in Microbiology. 9: 3152. doi: 10.3389/fmicb.2018.03152.b

2. Barlocher, F. and Marvanova, L. (2010). Aquatic hyphomycetes (Deutromycotina) of the Atlantic Maritime Ecozone. In: Assessment of Species Diversity in the Atlantic maritime Ecozone. Edited by D.F. Mc Alpine and I.M. Smith. NRC Research Press, Ottawa, Canada. 1-37.

3. Barlocher, F. (1987). Aquatic hyphomycetes spora in 10 streams of New Brunswick and Nova Scotia. Canadian 
Journal of Botany. 65: 76-79.

4. Belwal, M. and Sati, S.C. (2001). Seasonal Periodicity of water borne conidial fungi in a freshwater stream at Jeolikot, Kumaun Himalaya. Journal of Indian Botanical Society. 80: 145-149.

5. Dang, C.K., Schindler, M., Chauvet, E. and Gessener, M.O. (2009). Temperature oscillations coupled with fungal communities can modulate warming effects on litter decomposition. Ecology. 90: 122-131. doi: 10.1890/07-1974.1.

6. Duarte, S., Fernandes, I., Nogueira, M.J.N., Cassio, F. and Pascoal, C. (2013). Temperature alters interspecific relationships among aquatic fungi. Fungal Ecology. 6: 187 -191. doi: 10.1016/j.funeco.2013.02.001.

7. Gulis, V., Su, R. and Kuehn, K. (2019). Fungal decomposition in freshwater environments. The Structure and Function of Aquatic Microbial Communities. Springer. 7: 121-155. doi: 10.1007/978-3-030-16775-2_5

8. Ingold, C.T. (1942). Aquatic Hyphomycetes of decaying alder leaves. Transactions of the British Mycological Society. 25: 339-417.

9. Ingold, C.T. (1975). An illustrated guide to aquatic and water borne Hyphomycetes (Fungi imperfecti) with notes on their biology. Freshwater Biological Association Scientific Publication No. 30 England. 96 pp.

10.Krauss, G.J., Sole, M., Krauss, G., Schlosser, D., Wesenberg, D. and Barlocher, F. (2011). Fungi in freshwaters: ecology, physiology and biochemical potential. Federation of European Microbiological Societies. 620-651. doi: 10.1111/j.1574-6976.2011.00266.x.
11.Pant, P. and Sati, S.C. (2018). Occurrence and distribution of Kumaun Himalayan Aquatic Hyphomycetes: Tetracladium. International Journal of Current Advanced Research. 7 (7): 14100-14105. http.//dx.doi.org/10.24327/ ijcar.2018.1410 5.25 45 .

12.Pant, P., Koranga, A. and Sati, S.C. (2019). Diversity and distribution of aquatic hyphomycetes in fresh water bodies of Nainital, Kumaun Himalaya, India. The International Journal of Plant Reproductive Biology. 11 (2): 107-113. doi: 10.14787/ijprb.2019.11.2.

13.Santos-Flores C.J. and Betancourt-Lopez C. (1997). Aquatic and Water-borne Hyphomycetes (Deutromycotina) In Streams of Puerto Rico (including records from other Neotropical locations). Caribbean Journal of Science. (2): 1-116.

14.Sati, S.C., Tiwari, N. and Belwal, M. (2002). Conidial aquatic fungi of Nainital, Kumaun Himalaya, India. Mycotaxon. 81: 445-455.

15.Sati, S.C., Bisht, S. and Arya P. (2009). Effect of temperature, $\mathrm{pH}$ and light on the growth of some aquatic hyphomycetes. Contribution to the Mycological ProgressSpringer. 413-423.

16.Sati, S.C., and Arya, P. (2009). Occurrence of water borne conidial fungi in relation to some physico-chemical parameters in a fresh water stream. Nature and Science. 7 (4): 20-28.

17.Sridhar, K.R. and Barlocher, F. (1993). Effect of temperature on growth and survival of free aquatic hyphomycetes. Sydowia. 45:337-387. 